Zhang X., Hu W., \& Oergel M. (2021). From skillacquisition to dynamic learning: Learning-oriented assessment in the sight translation classroom. Current Trends in Translation Teaching and Learning E, 8, 313 359. https://doi.org/10.51287/cttle202110

\title{
FROM SKILL-ACQUISITION TO DYNAMIC LEARNING: LEARNING-ORIENTED ASSESSMENT IN THE SIGHT TRANSLATION CLASSROOM
}

Xueni Zhang

Durham University

Wan $\mathrm{Hu}$

Xi'an Jiaotong-Liverpool University

Maike Oergel

The University of Nottingham

\section{Abstract}

Assessment, previously associated with the evaluation of learning outcomes, has recently been recognised as an integral part of the learning process. Learning-oriented assessment (LOA) is an educational model that foregrounds the role of assessment in classroom-based learning activities. However, in translator education, assessment is mostly approached from a skill-acquisition perspective; translation is regarded more as a skill to acquire than as a learning activity. This article presents an alternative view of assessment in translator education by presenting the findings of a 12-week case study, conducted with 20 students registered in a sight translation module, which based its teaching (and assessment) on LOA principles. 
Zhang X., Hu W., \& Oergel M. (2021). From skillacquisition to dynamic learning: Learning-oriented assessment in the sight translation classroom. Current Trends in Translation Teaching and Learning E, 8, 313 359. https://doi.org/10.51287/cttle202110

Classroom observation was conducted to align LOA with the classroom context, and follow-up interviews were carried out to investigate students' perceptions regarding the in-class activities. In order to evaluate the feasibility and accountability of the model, the three tenets of LOA were aligned with module design and discussed alongside students' perceptions. The findings indicate the suitability of incorporating LOA into translator education, with implications for translation trainers and researchers concerning the integration of assessment and learning.

Keywords: learning-oriented assessment, translator education, sight translation

\section{INTRODUCTION}

Curriculum, pedagogy, and assessment are three pillars central to education. Curriculum and pedagogy are associated with the learning process, while assessment often denotes the learning outcome. For this reason, assessment used to be associated with examinations, testing, tension, and anxiety. This neglects the ultimate aim of assessment, which is to promote learning, rather than to burden learners with fear of examination. In this regard, the learning role of assessment has been attended to (e.g., Boud, 2000; Boud \& Falchikov, 2007; Carless, 2017). However, the double duty of grading and learning entails a potential challenge regarding how to integrate learning elements into the measuring role. Compromise between the two needs to be considered when designing assessment practices. 
Zhang X., Hu W., \& Oergel M. (2021). From skillacquisition to dynamic learning: Learning-oriented assessment in the sight translation classroom. Current Trends in Translation Teaching and Learning E, 8, 313 359. https://doi.org/10.51287/cttle202110

In translator education, it is traditionally believed that translation expertise is accumulated through repetitive practice, and that novices need to undergo intensive translation training to gain this expertise (Kelly, 2005, p. 11). Thus, the teaching of translation either focuses on helping students to learn various techniques to produce an acceptable translation, or on enhancing the translation skill in terms of efficiency and outcome. This approach values practice and skill training, but learning elements such as construction and sharing of knowledge are easily overlooked. However, as translation is increasingly viewed as an independent academic discipline (Munday, 2012, pp. 7-24), the skill acquisition principle is likely to be insufficient to account for the multiple aspects of translator education, such as cooperation and feedback, and an educational perspective is needed. As noted by Kelly (2005), assessment should be linked to intended learning outcomes and curriculum design; it should also be realistic and real-world oriented, so that education is aligned with graduates' future development. Learning and assessment should be learner-centred and socially constructed (Kiraly, 2000). Assessment is recognised as a more dynamic, formative, and continuous process than a one-off exam. Despite the fact that scholars have formulated and introduced some comprehensive assessment methods into translation classrooms (e.g., GalánMañas \& Hurtado Albir, 2015; Huertas Barros \& Vine, 2019; Veiga Díaz \& García González, 2016), little research has focused on applying educational theories or models to assessment. There is a lack of 
Zhang X., Hu W., \& Oergel M. (2021). From skillacquisition to dynamic learning: Learning-oriented assessment in the sight translation classroom. Current Trends in Translation Teaching and Learning E, 8, 313 359. https://doi.org/10.51287/cttle202110

theoretical support rationalising the ways in which assessment is practised.

To address the research gap, the current study introduces learning-oriented assessment (LOA) into a sight translation classroom. Despite having been introduced into the teaching of other subjects such as language learning, multimedia, and education (Carless, 2007; Jones \& Saville, 2016; Keppell \& Carless, 2006), LOA practices are not currently common in translator education. The key principles of LOA are integrated into classroom-based assessment tasks, and students' experiences and perceptions are gathered through classroom observations and interviews. The study offers an alternative view of how translation is understood as a socially constructed educational practice that integrates knowledge and competence in a dynamic manner and brings student agency to the fore through learning and assessment activities, rather than merely as a skill to be acquired. Assessment, in this context, is approached from the perspective of learning and teaching and integrated into the educational ecology. It contributes to the understanding of learning and assessment, and, more specifically, to how the learning process of translation is mediated by assessment tasks.

\section{LITERATURE REVIEW}

\subsection{Assessment in Translator Education}

In translation studies, assessment is often considered to indicate the quality of translation work. Although 
Zhang X., Hu W., \& Oergel M. (2021). From skillacquisition to dynamic learning: Learning-oriented assessment in the sight translation classroom. Current Trends in Translation Teaching and Learning E, 8, 313 359. https://doi.org/10.51287/cttle202110

the translation product and its quality are the ultimate aim in all forms of translation activities, this outcome alone cannot account for a holistic picture of translator education, especially in terms of the changes that one has to undergo in growing from a novice learner into a professional translator. In the educational context, assessment is not only associated with the translation product, but also with the individual novice translator, as well as with the translation activity undertaken. Discussions revolving around translation quality assessment (House, 1997; Larose, 1998; Reiss, 2000) were followed by a more competence-based, learnercentred approach (Kelly, 2005; Kiraly, 2000; PACTE group, 2003). An array of classroom-based assessment tools, tasks, and activities were then examined (e.g., Galán Mañas, 2016; Han \& Fan, 2020; Huertas Barros \& Vine, 2019). Assessment has been approached from a variety of angles, including outcome-based assessment, assessment and translator competence, classroom-based assessment, assessment issues at the programme level, and profession-oriented assessment (See Table 1 for an overview).

Table 1. Literature on assessment in translator education

\begin{tabular}{|c|c|c|}
\hline Research focus & Main topic(s) & Key literature \\
\hline $\begin{array}{l}\text { Outcome-based } \\
\text { assessment }\end{array}$ & $\begin{array}{l}\text { - Developing } \\
\text { frameworks or } \\
\text { criteria for } \\
\text { assessing } \\
\text { translation quality }\end{array}$ & $\begin{array}{l}\text { Al-Qinai (2000); } \\
\text { House (1977, } \\
\text { 1997, 2015); } \\
\text { Larose (1998); } \\
\text { Williams (2004); } \\
\text { Reiss (2000) }\end{array}$ \\
\hline $\begin{array}{l}\text { Assessment and } \\
\text { translator } \\
\text { competence }\end{array}$ & $\begin{array}{l}\text { - Recording and } \\
\text { assessing the } \\
\text { development of }\end{array}$ & $\begin{array}{l}\text { PACTE group } \\
\text { (2003); Hurtado } \\
\text { Albir (2007, }\end{array}$ \\
\hline
\end{tabular}


Zhang X., Hu W., \& Oergel M. (2021). From skillacquisition to dynamic learning: Learning-oriented assessment in the sight translation classroom. Current Trends in Translation Teaching and Learning E, 8, 313 359. https://doi.org/10.51287/cttle202110

\begin{tabular}{|c|c|c|}
\hline & $\begin{array}{l}\text { translator sub- } \\
\text { competencies } \\
\text { - Competence-based } \\
\text { curriculum design } \\
\text { and assessment } \\
\text { instruments }\end{array}$ & $\begin{array}{l}\text { 2015); Galán- } \\
\text { Mañas and } \\
\text { Hurtado Albir } \\
(2015)\end{array}$ \\
\hline $\begin{array}{l}\text { Classroom-based } \\
\text { assessment }\end{array}$ & $\begin{array}{l}\text { - Proposing and } \\
\text { adopting innovative } \\
\text { assessment tools } \\
\text { - Creating } \\
\text { assessment rubrics } \\
\text { for translation } \\
\text { assignments }\end{array}$ & $\begin{array}{l}\text { Galán-Mañas } \\
\text { (2016); Veiga } \\
\text { Díaz and García } \\
\text { González (2016); } \\
\text { Su (2019); } \\
\text { Huertas Barros } \\
\text { and Vine (2019); } \\
\text { Hurtado Albir } \\
\text { and Pavani } \\
\text { (2018) }\end{array}$ \\
\hline $\begin{array}{l}\text { Assessment } \\
\text { issues at } \\
\text { programme level }\end{array}$ & $\begin{array}{l}\text { - Evaluating } \\
\text { assessment } \\
\text { practices in existing } \\
\text { translation } \\
\text { programmes } \\
\text { - Examining teacher } \\
\text { or learner } \\
\text { experiences with } \\
\text { regard to } \\
\text { assessment } \\
\end{array}$ & $\begin{array}{l}\text { Kelly (2005); } \\
\text { Huertas Barros } \\
\text { and Vine (2018); } \\
\text { Abdel Latif } \\
(2018) ; \mathrm{Hu} \\
(2018 b)\end{array}$ \\
\hline $\begin{array}{l}\text { Profession- } \\
\text { oriented } \\
\text { assessment }\end{array}$ & $\begin{array}{l}\text { - Inviting } \\
\text { professionals to } \\
\text { participate in the } \\
\text { assessment process } \\
\text { - Linking with } \\
\text { professional } \\
\text { accreditation or } \\
\text { market entry tests }\end{array}$ & $\begin{array}{l}\mathrm{Li}(2019) ; \mathrm{Hu} \\
(2018 \mathrm{a}) ; \text { Orlando } \\
(2011)\end{array}$ \\
\hline
\end{tabular}

This section will mainly review classroom-based assessment, as this approach is most relevant to the study and constitutes its background. In previous research in this area, some studies have proposed reflections and proposals for assessment choices. For example, Galán-Mañas and Hurtado Albir (2015) 
Zhang X., Hu W., \& Oergel M. (2021). From skillacquisition to dynamic learning: Learning-oriented assessment in the sight translation classroom. Current Trends in Translation Teaching and Learning E, 8, 313 359. https://doi.org/10.51287/cttle202110

put forward a set of assessment instruments tailored to different assessment goals. By suggesting wideranging options for assessment tools, they argued that rather than judging the educational outcome solely by appraising the resulting translation work, assessment should also be designed to examine what is involved in the process, such as translation strategies and problem-solving skills. Veiga Díaz and García González (2016) applied the concept of constructive alignment to assessment practices, proposing that learning outcomes, tasks, and assessment methods should be coordinated, and that assessment instruments should be integrated to address both product- and process-related errors through continued support and feedback. They also proposed combining four types of tasks (questionnaires, portfolios, projects and exams) for a constructively aligned assessment.

Apart from proposals, a number of small-scale, classroom-based studies presented exemplary, contextualised assessment practices. For instance, Galán-Mañas (2016) exemplified the use of a learning portfolio in a six-credit English-Spanish translation module for both formative and summative purposes. The study highlighted that learning portfolios improve learner autonomy, reflective and critical thinking, and self-assessment skills. Hurtado Albir and Pavani (2018) empirically tested a multidimensional summative assessment design, with undergraduate language students using a series of criterion-referenced and competencebased assessment instruments and tasks. The innovative assessment design was compared with 
Zhang X., Hu W., \& Oergel M. (2021). From skillacquisition to dynamic learning: Learning-oriented assessment in the sight translation classroom. Current Trends in Translation Teaching and Learning E, 8, 313 359. https://doi.org/10.51287/cttle202110

the traditional examination task and was found implicative for the acquisition of translation competence. Su (2019) examined the translation quality evaluated by peer students in an EnglishChinese simultaneous interpreting module, suggesting peer comments on some aspects of translation quality might stimulate reflective thinking and should be emphasised in teaching. Lee (2005) presented the use of self-assessment in a Korean-English interpreting classroom, while Li (2018) compared student self-assessment with teacher assessment in a Chinese-English sight translation context, suggesting the positive washback effect of the assessment tool. Han and Fan (2020) examined self-assessment in an EnglishChinese interpreting module from the students' perspective. Lastly, Huertas Barros and Vine (2019) presented a case study of collaborative transcreation module design. They addressed the use of student collaboration in constructing criteria in order to improve assessment literacy.

The literature above discusses assessment from a more practical, classroom-based vantage point. The traditional view of translation as a skill-acquisition activity, and of assessment as an examination, in which a translation task is performed, then appraised through a rank or score, is being replaced by a more dynamic, multi-layered perspective. Formative assessment tools such as learning portfolios and collaborative tasks are emphasised as equally important as translation quality, and the learning process is considered to be as important as the outcome. Having said that, these studies only 
Zhang X., Hu W., \& Oergel M. (2021). From skillacquisition to dynamic learning: Learning-oriented assessment in the sight translation classroom. Current Trends in Translation Teaching and Learning E, 8, 313 359. https://doi.org/10.51287/cttle202110

addressed a single element to be emphasised in learning, or promised ideal classrooms rather than suggesting concrete ways of achieving them. Learning features need to be distilled in order to sketch out the classroom dynamics as a whole. Meanwhile, classroom-based studies are grounded on case-based evidence, few of which are endowed with support from theory. To shed light on the transferability of assessment practices, a link between practice and theory is needed, to position assessment as an integrated component of the educational ecology.

\subsection{Learning-oriented Assessment: Definition, Principles and Rationales}

The educational model of learning-oriented assessment (LOA) considers assessment to be the facilitator of learning (Carless, 2007, 2009, 2015). It emphasises the aspects of assessment that promote learning more than measurement, regardless of assessment forms. For example, learning can be achieved through either formative or summative assessment, as long as a productive and motivated learning process is presented. Figure 1 shows the LOA framework.

LOA is defined as a reconciliation of the certification and learning purpose. It is constructed based on three major principles, and its implementation is jointly shaped by tutors' and students' understanding and experiences. The first principle of LOA emphasises its formative aspect. 
Zhang X., Hu W., \& Oergel M. (2021). From skillacquisition to dynamic learning: Learning-oriented assessment in the sight translation classroom. Current Trends in Translation Teaching and Learning E.

Assessment should be incorporated as a regular part of learning tasks across a period of study, rather than a short-term evaluation of learning outcomes at the

Figure 1. The framework of learning-oriented assessment (Carless, 2009)
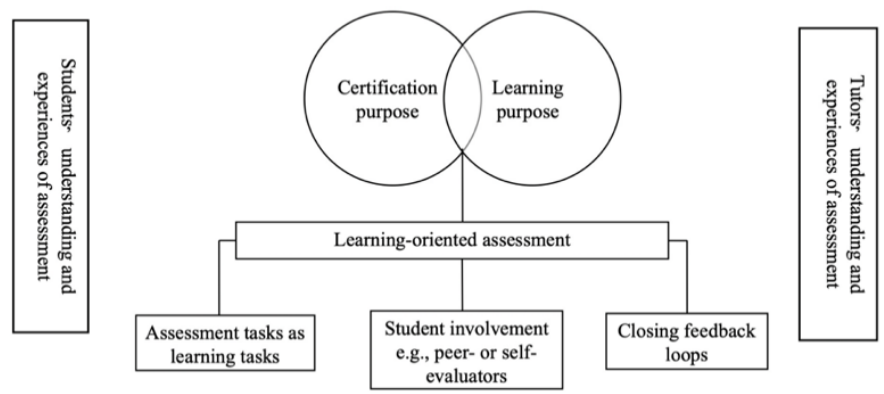

end of a module. Assessment tasks are associated with problem-solving, collaboration and authenticity, which reflect "real-world applications of the subject matter" (Carless, 2007, p. 59). The second principle of student involvement denotes learners' engagement with assessment criteria and the quality of learning outcome, as well as evaluation practices performed by themselves or with peer learners. Through these activities, learners are expected to understand how assessment criteria are constructed, how assessment works, and what is expected in the assessment (Carless, 2009). LOA classrooms often prioritise self- and peer assessment tasks. Self-assessment helps learners to situate themselves in relation to the learning goals, and 
Zhang X., Hu W., \& Oergel M. (2021). From skillacquisition to dynamic learning: Learning-oriented assessment in the sight translation classroom. Current Trends in Translation Teaching and Learning E.

appropriately adjust their understanding as they pursue these goals (Sadler, 1989). Peer assessment enables learners to interact and learn from each other, allowing them to build up shared knowledge and foster collaborative skills. It denotes learning as a collaborative activity, echoing the social constructivist view that knowledge is collaboratively constructed (Vygotsky, 1978). With regard to feedback, Carless (2015) noted that it is what students can do with feedback that matters, and that feedback without response is ineffective. Students' disregard of assessment feedback or lack of response to assessment results can be a shortcoming of traditional assessment. Thus, closing the feedback loop is crucial to ensuring learner uptake and enabling feedback to feed into future learning. Accordingly, feedback should be timely and effective, and can be acted upon. Table 2 shows the key characteristics of LOA principles, as well as design features of typical LOA tasks.

Table 2. LOA principles and task design features (adapted from Carless, 2007, 2009, 2015)

\begin{tabular}{|c|c|c|}
\hline Principles & Characters & Task design features \\
\hline $\begin{array}{l}\text { Assessment } \\
\text { tasks as } \\
\text { learning } \\
\text { tasks }\end{array}$ & $\begin{array}{l}\text { - Promote the right kind } \\
\text { of learning disposition } \\
\text { - Mirror real-world } \\
\text { applications of the } \\
\text { subject matter } \\
\text { - Lead to long-term } \\
\text { evenly distributed } \\
\text { learning efforts over a } \\
\text { course rather than } \\
\text { memorisation or } \\
\text { surface learning }\end{array}$ & $\begin{array}{l}\text { - Tasks should be } \\
\text { constructively aligned with } \\
\text { curriculum objectives and } \\
\text { content } \\
\text { - Assignments are generally } \\
\text { preferred to examinations } \\
\text { - Tasks engage learners with } \\
\text { work overtime rather than } \\
\text { being one-shot } \\
\text { - Tasks are real-world, } \\
\text { authentic, cooperative } \\
\text { rather than competitive } \\
\text { - Tasks show some degree of }\end{array}$ \\
\hline
\end{tabular}


Zhang X., Hu W., \& Oergel M. (2021). From skillacquisition to dynamic learning: Learning-oriented assessment in the sight translation classroom. Current Trends in Translation Teaching and Learning E.

\begin{tabular}{|c|c|c|}
\hline & & student choice \\
\hline $\begin{array}{l}\text { Student } \\
\text { involvement }\end{array}$ & $\begin{array}{l}\text { - Engage learners with } \\
\text { assessment criteria and } \\
\text { standards } \\
\text { - Develop evaluative } \\
\text { expertise in learners } \\
\text { - Facilitate assessment } \\
\text { transparency and } \\
\text { enhance mutual trust }\end{array}$ & $\begin{array}{l}\text { - Learners are engaged in } \\
\text { identifying, drafting, } \\
\text { summarising or using } \\
\text { assessment criteria } \\
\text { - Learners are engaged with } \\
\text { quality exemplars } \\
\text { - Use of peer assessment, } \\
\text { peer feedback or self- } \\
\text { evaluation }\end{array}$ \\
\hline $\begin{array}{l}\text { Closing } \\
\text { feedback } \\
\text { loops }\end{array}$ & $\begin{array}{l}\text { - Promote engagement } \\
\text { with feedback } \\
\text { - Feedback is effective } \\
\text { - Feedback can be acted } \\
\text { upon }\end{array}$ & $\begin{array}{l}\text { - Feedback focuses on } \\
\text { learning rather than on } \\
\text { marks or on students } \\
\text { themselves } \\
\text { - Feedback is timely and } \\
\text { comprehensive } \\
\text { - Two-stage assignments; } \\
\text { feedback that promotes } \\
\text { self-monitoring; feedback } \\
\text { that is generally most } \\
\text { timely and forward-looking }\end{array}$ \\
\hline
\end{tabular}

While learning and assessment are much explored in general education studies, the two concepts are seldom integrated into translator education, since translation is mostly recognised as a skill to acquire rather than knowledge to learn. As a significant number of translation programmes are being delivered in higher education institutions around the world, it is timely and necessary to consider translation from the perspective of learning and education. The elements emphasised by LOA, such as authenticity and cooperation, link education to real-world tasks, addressing the professional orientation of translator education while highlighting the nature of learning. Meanwhile, LOA offers an alternative interpretation of how 
Zhang X., Hu W., \& Oergel M. (2021). From skillacquisition to dynamic learning: Learning-oriented assessment in the sight translation classroom. Current Trends in Translation Teaching and Learning E.

translation can be learned, other than as a skill to be acquired. This chimes with what Kiraly (2000) suggested in building up a social constructivist approach to translator education. In this approach, the focus of translation teaching is supposed to shift from being teacher-centred or learner-centred to learning-centred. Within this model, assessment is not instrumental, but contextualised and learningoriented. Learners are active players in the learning process rather than being assessed. Translation is collaboratively learned rather than acquired as a skill. Hence, LOA is enlightening for translator education in terms of the alignment between learning and assessment. To introduce a classroombased case of LOA, research questions are devised as follows:

RQ1 How is the LOA model aligned with the module design?

RQ2 To what extent is the model feasible and accountable for the module?

RQ3 What are the implications for positioning translator education as a learning activity instead of a skill-acquisition process?

\section{ALIGNING LOA WITH THE SIGHT TRANSLATION CLASSROOM: DESIGN AND IMPLEMENTATION}

\subsection{Research Context: the Sight Translation Classroom}

The study was conducted with third-year undergraduate students in a BA Translation and 
Zhang X., Hu W., \& Oergel M. (2021). From skillacquisition to dynamic learning: Learning-oriented assessment in the sight translation classroom. Current Trends in Translation Teaching and Learning E.

Interpreting programme at a top-tier university in Beijing, China. The sight translation module, being introduced at the beginning of the third academic year, aims to enable students to further develop their professional skills to support simultaneous interpreting through translating topic-based written texts. Students enrolling in this module have had prior theoretical knowledge and hands-on experience in written translation, but little practice in oral interpreting. This means that they have received an adequate amount of translation exercises and built up good bilingual competence and translation strategies, and are prepared to face the cognitive demand for multi-tasking skills required in interpreting tasks.

The module consists of 12 sessions, each featuring a text excerpted from written speech or news reports as material for sight translation exercises. These texts are selected in order to prepare students with real-life sight translation scenarios. Texts used for the first six sessions are in English, to be translated into Chinese. In the following six sessions, Chinese and English texts are used interchangeably. The translation texts are sequenced in terms of the degree of difficulty. Chinese-English translation exercises are scheduled after English-Chinese translation on the grounds that translating from Chinese into English seems to pose more challenges for these English-L2 students than vice versa as observed in past translation modules.

Each session lasts for two hours, involving a number of classroom activities collaboratively carried out by 
Zhang X., Hu W., \& Oergel M. (2021). From skillacquisition to dynamic learning: Learning-oriented assessment in the sight translation classroom. Current Trends in Translation Teaching and Learning E.

the teacher and students (see Figure 2). Typically, the teacher firstly introduces the session topic, which is related to the text to be translated and engages students in open discussion. Then the teacher distributes written texts for practice to students, asking them to pre-read the texts within a time limit. On average, each meeting comprises an exercise of a written text of around 2 to 3 pages in English or Chinese. Occasionally when the text is difficult for students, the teacher provides guided text analysis that helps them to comprehend the text content and identify translation units. This includes chunking the sentences and explaining complex lexical and semantic meanings in the Chinese language. Then, students are put in pairs for the first practice. They are instructed to take turns in sharing their renditions with peers, and comment on each other's performance. After peer practice on the entire text, some of the students are encouraged to present their renditions in front of the class. The teacher gives feedback on their renditions and initiates class discussion on aspects such as translation pitfalls and strategies. An after-class assignment is distributed to students which requires them to work in the same pairs to design a peer evaluation worksheet and record each other's inclass performance using it. The worksheet needs to include, but is not limited to, parameters of translation quality, scoring, and detailed descriptions or comments regarding the performance (See Appendix 1 for the assignment requirement and Appendix 2 for an example by students). This is designed to stimulate students' understanding of the translation quality and 
Zhang X., Hu W., \& Oergel M. (2021). From skillacquisition to dynamic learning: Learning-oriented assessment in the sight translation classroom. Current Trends in Translation Teaching and Learning E.

assessment literacy, as well as reflections on the classroom activities. Students are required to present the assignment in the next session to come. The inclass peer task constitutes $30 \%$ of the final mark, and the after-class assignment of worksheet design constitutes $30 \%$. A summative examination involves sight translating a new Chinese text and an English one to the teacher in a face-to-face manner, and the grade given by the teacher accounts for $40 \%$ of the final mark.

Figure 2. The procedure of the module session

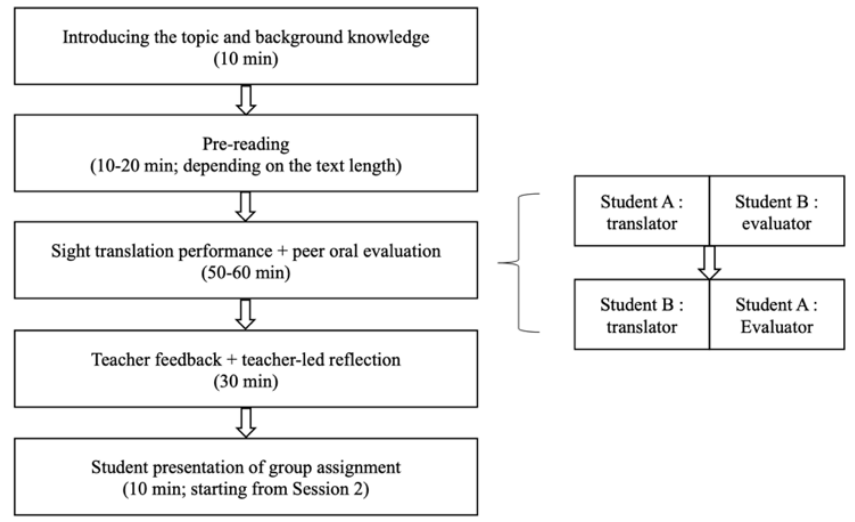

\subsection{Participants, Data Collection and Analysis}

Twenty students who enrolled in the sight translation module participated in this study (17 females and 3 males). They were all in their early twenties. All participants were informed that the 
Zhang X., Hu W., \& Oergel M. (2021). From skillacquisition to dynamic learning: Learning-oriented assessment in the sight translation classroom. Current Trends in Translation Teaching and Learning E.

study included their in-class performance, their hand-in peer evaluation worksheet and that a postlearning interview would be conducted for the purpose of research, and all consented to take part.

Classroom observation, students' worksheets and indepth interviews were collected as data for this study. Classroom observation was conducted to understand the context and curriculum progression while capturing students' behaviours and engagement. Students' evaluation worksheets were important evidence for identifying their translation pitfalls and acknowledge their evaluation preferences. Interviews were devised in an exploratory nature towards how students respond to and interpret the classroom activities conducted, allowing a degree of freedom and flexibility in expressing views and attitudes. An interview guide was developed to ensure key topics and issues are addressed. Probing questions were raised to capture more personalised experiences or views. The interviews were conducted in Chinese, the first language of the participants. Interview audio recordings were transcribed, translated, and coded. The data was run through thematic coding after multiple readings and interpretations of the transcripts. Overarching themes were identified from data coding and analysis and were presented in research findings.

\section{ALIGNING LOA WITH THE SIGHT TRANSLATION CLASSROOM: FEASIBILITY AND ACCOUNTABILITY}


Zhang X., Hu W., \& Oergel M. (2021). From skillacquisition to dynamic learning: Learning-oriented assessment in the sight translation classroom. Current Trends in Translation Teaching and Learning E.

As mentioned previously, the three principles of LOA are assessment tasks as learning tasks, student involvement in assessment activities, and closing feedback loops (Carless, 2009). We now align the model with the module design and discuss the feasibility of the model in relation to classroom activities as well as its accountability from learners' perspectives. Table 3 shows the alignment between LOA principles and the design features of this module.

Table 3. Alignment of LOA principles and Sight Translation module design features

\begin{tabular}{|l|l|l|}
\hline $\begin{array}{l}\text { LOA } \\
\text { principles }\end{array}$ & Connotations & Module design features \\
\hline \multirow{4}{*}{$\begin{array}{l}\text { Assessment } \\
\text { tasks as } \\
\text { learning } \\
\text { tasks }\end{array}$} & $\begin{array}{l}\text { 1. Long-term, } \\
\text { accumulated and } \\
\text { engaged learning }\end{array}$ & $\begin{array}{l}\text { Each student is paired with another } \\
\text { to practice sight translation and } \\
\text { comment on each other over the } \\
\text { course of the 12-week module. } \\
\text { (Students are assigned into different } \\
\text { pairs during individual meetings.) }\end{array}$ \\
\cline { 2 - 4 } & $\begin{array}{l}\text { They are given authentic translation } \\
\text { tasks (e.g., texts from real-world } \\
\text { speeches or news reports) to } \\
\text { perform in front of their peers } \\
\text { within a time limit; they are } \\
\text { required to treat the task as mock } \\
\text { interpreting. }\end{array}$ \\
\cline { 2 - 4 } & $\begin{array}{l}\text { 3. Cooperative } \\
\text { nature }\end{array}$ & $\begin{array}{l}\text { Each pair is given discretion to } \\
\text { manage the practice, discussion, } \\
\text { and evaluation within the time limit. }\end{array}$ \\
\hline \multirow{3}{*}{$\begin{array}{l}\text { Student } \\
\text { involvement }\end{array}$} & $\begin{array}{l}\text { 1. Students' } \\
\text { development and } \\
\text { use of assessment } \\
\text { criteria }\end{array}$ & $\begin{array}{l}\text { They are given a group assignment } \\
\text { that requires designing and utilising } \\
\text { a peer evaluation worksheet; they } \\
\text { are encouraged to construct } \\
\text { assessment criteria that they believe } \\
\text { to be important. }\end{array}$ \\
\cline { 2 - 3 } & $\begin{array}{l}\text { 2. Students' } \\
\text { development of }\end{array}$ & $\begin{array}{l}\text { They are involved in in-class oral } \\
\text { commentary on translation quality, }\end{array}$ \\
\hline
\end{tabular}


Zhang X., Hu W., \& Oergel M. (2021). From skillacquisition to dynamic learning: Learning-oriented assessment in the sight translation classroom. Current Trends in Translation Teaching and Learning E.

\begin{tabular}{|l|l|l|}
\hline \multirow{1}{*}{} & $\begin{array}{l}\text { evaluative } \\
\text { expertise }\end{array}$ & $\begin{array}{l}\text { as well as comprehensive } \\
\text { construction of assessment criteria } \\
\text { in written form. }\end{array}$ \\
\cline { 2 - 3 } & $\begin{array}{l}\text { 3. Assessment } \\
\text { transparency and } \\
\text { mutual trust }\end{array}$ & $\begin{array}{l}\text { The mode of turn-taking and role- } \\
\text { switching between translator and } \\
\text { evaluator ensures the assessment } \\
\text { process is transparent and } \\
\text { encourages mutual understanding. }\end{array}$ \\
\hline $\begin{array}{l}\text { Closing } \\
\text { feedback } \\
\text { loops }\end{array}$ & $\begin{array}{l}\text { 1. Effective } \\
\text { feedback }\end{array}$ & $\begin{array}{l}\text { Overall teacher feedback addresses } \\
\text { common translation pitfalls and } \\
\text { strategies, as well as evaluation } \\
\text { tasks. }\end{array}$ \\
\cline { 2 - 3 } & $\begin{array}{l}\text { 2. Timely and } \\
\text { comprehensive } \\
\text { feedback }\end{array}$ & $\begin{array}{l}\text { Peer feedback is oral, detail- } \\
\text { oriented and immediate. }\end{array}$ \\
\hline
\end{tabular}

\subsection{Promoting Continued, Cooperative, and Real-world Oriented Learning}

In the classroom, learning is primarily carried out through the turn-taking of translation and evaluation (60 min out of $120 \mathrm{~min}$ ). This means that assessment is not executed at the end of the course, or at the end of a certain period of studying, in the form of grading; rather, it is concurrent with learning. In other words, assessment is incorporated into the learning task instead of being separated from learning. This echoes with the first principle of LOA that the function of assessment is to facilitate cumulative learning. Further, in order to make assessment tasks reflective of real-world, authentic work, texts for translation practices were selected from up-to-date, mainstream news reports or speeches, and students were asked to play the role of translator and audience by turns. Also, working in pairs required a sense of team spirit in terms of the distribution of tasks and receipt of opinions. What 
Zhang X., Hu W., \& Oergel M. (2021). From skillacquisition to dynamic learning: Learning-oriented assessment in the sight translation classroom. Current Trends in Translation Teaching and Learning E.

students reflected in 4.1.1. Self-motivation and engagement corresponds to the kind of learning we wish to promote, and the feature of task authenticity is reflected in 4.1.2. Simulation of real-world tasks. 4.1.3. Cooperative learning echoes with the cooperative nature of LOA.

\subsubsection{Self-motivation and engagement}

Students reported that classroom activities have an impact on how they understand and approach learning. Some even stated that passing the examination is no longer the goal of learning, compared to learning itself.

I don't worry too much about the final exam because what we practised and discussed in class is far more useful and meaningful than a single test. What is important is that we learn something new every time. At least in this session, I am not a passive learner. $[\mathrm{S} 10]^{1}$

Others mentioned that working in pairs makes them more engaged in feedback. They stated that traditional teacher-centred teaching could put pressure on them, making introverted students more self-enclosed; in contrast, working with peers makes them more relaxed and engaged:

\footnotetext{
${ }^{1}$ The transcript excerpts are transcribed verbatim from interviews and translated into English.
} 
Zhang X., Hu W., \& Oergel M. (2021). From skillacquisition to dynamic learning: Learning-oriented assessment in the sight translation classroom. Current Trends in Translation Teaching and Learning E.

I like the class environment. [...] I know some classmates, including myself, feel uncomfortable speaking in front of the cl ass because we are afraid to make mistakes or simply worry that our delivery is not good enough. We are really worried about being criticised when making mistakes or getting too nervous to translate. I've always avoided negative comments. No thinking again, no reflecting back on the mistakes. [...] But peer feedback is more of an opportunity for reflection instead of an urge for improvements. I guess we are more relaxed in front of peer students rather than a teacher or any high-profile experts. So, I am willing to take feedback from peers. And I would even argue with them if I disagree with them. [S3]

A few expressed that they are more motivated, simply because of peer learning. They were encouraged to keep practising autonomously in pairs in both in-class and extracurricular manners. One student said that he would not be determined and driven to enhance his translation skills if the peer evaluation activity had not been carried out in class:

If I practice on my own, I would probably get bored and quit quite early. But with my partner, I know I've got some company and I'm more motivated to do the exercise. [S11]

This finding resonates with self-regulated learning 
Zhang X., Hu W., \& Oergel M. (2021). From skillacquisition to dynamic learning: Learning-oriented assessment in the sight translation classroom. Current Trends in Translation Teaching and Learning E.

encouraged by feedback (Butler \& Winne, 1995), as well as the "motivational potential" of peer assessment (McGarr \& Clifford, 2013, p. 679).

\subsubsection{Simulation of real-world tasks}

Students reflected that the classroom activities created authenticity in the learning environment to help them get familiar with the real-world interpreting tasks. One of the students stated that being watched by her peer gave her stress, as if she was performing for a real conference occasion:

I felt nervous when I was watched by my peer. It's kind of like she is my client and I am translating for her. [S14]

Another student echoed his fellow student's points and shared his understanding of peer practice simulating real-world translation scenarios:

I can understand why we have to perform to each other because when you are doing real translation, you don't speak to yourself. You speak to others. Performing in front of a partner means you have an audience. As long as there is attention, you never treat it as a drill but as an authentic interpreting occasion. This matters because if what I practice is nothing to do with what happens in real interpreting, then the practice is not useful at all. [S6] 
Zhang X., Hu W., \& Oergel M. (2021). From skillacquisition to dynamic learning: Learning-oriented assessment in the sight translation classroom. Current Trends in Translation Teaching and Learning E.

It is worth noting that interpreting training is closely associated with professional contexts, thus there is a natural inclination in the pedagogy of interpreting that teaching should include as many professional elements as possible (Pöchhacker, 2003, pp. 177189). One of the ways to bridge the gap between learning and the profession is to keep training tasks as authentic as possible.

\subsubsection{Cooperative learning}

Students reported that the classroom activities offered them opportunities to collaboratively identify and discuss challenging issues in the process of understanding and translating. Since they are of similar linguistic competence, it is relatively easy for them to find a shared perspective on message decoding, translation pitfalls, translation strategies, and issues of oral delivery. Some students also stated that peer evaluation tasks enabled them to pinpoint errors and make corrections in a more collegial style, from which both the translator and the evaluator can benefit:

We often encounter problems in aspects like understanding the original text or giving an appropriate translation. Then we would stop there and discuss where the problem is with the sentence and how to get a better solution. I like this learning style because if we don't understand a question well, we can work together to figure it out. [S3]

Moreover, students felt that the tasks created an 
Zhang X., Hu W., \& Oergel M. (2021). From skillacquisition to dynamic learning: Learning-oriented assessment in the sight translation classroom. Current Trends in Translation Teaching and Learning E.

environment for the exchange of ideas and reflection:

Sometimes we could make similar mistakes like not understanding the sentence fully and correctly or translating it into something wrong. Then one of us would point out the mistake, and we would discuss how we went wrong. It is always better than doing it by oneself. [S9]

They also believed that it is necessary to include collaborative learning in translation classrooms. They reflected that the exposure to diverse viewpoints and ability to cope with conflicting opinions is crucial, as there is no straight answer or standard strategy in any translation task:

When we have different opinions, we would argue with each other. And sometimes even if we talk a lot, neither of us would be willing to compromise. It seems that such discussion would be a waste of time, but we both know there is not a standardised answer for translation and the process of discussing and arguing in fact helps us decide the best solution. [S15]

\subsection{Building up Assessment Skills}

Collaboratively constructing assessment criteria has been introduced as an innovative method to address assessment literacy in translator education (Huertas Barros and Vine, 2019). In line with the LOA's 
Zhang X., Hu W., \& Oergel M. (2021). From skillacquisition to dynamic learning: Learning-oriented assessment in the sight translation classroom. Current Trends in Translation Teaching and Learning E.

second principle, which aims to develop learners' assessment literacy and involve them in using assessment criteria, three core tasks - peer practice, peer feedback, and designing the peer evaluation worksheet - were part of the module design. Specifically, each student was involved in hands-on translation or needed to pay attention to others' performance for most of the class time. This ensures they were fully engaged in the assessment. More importantly, evaluation tasks enabled them to develop evaluative expertise as well as critical thinking ability. In peer feedback, they were engaged with what defines a good-quality translation product, what criteria or standards to refer to when judging translation, what competencies a qualified translator is supposed to possess, and the translation pitfalls, translation strategies and skills to consider in the process. The written assignment then allowed for organised reflections on these issues. Teacher-led discussion and group presentation of the written assignment further invited the exchange of ideas. For example, data from students' handed-in assignments shows diverse thinking on translation quality. Some believe information accuracy and wording choice are essential, while others prioritise oral delivery and the tone and speed of speech. Students took assessment literacy as an essential part of learning, which is reflected in 4.2.1. Assessment literacy. 4.2.2. Assessment as a transferable skill is an additional benefit brought up by students.

\subsubsection{Assessment literacy}


Zhang X., Hu W., \& Oergel M. (2021). From skillacquisition to dynamic learning: Learning-oriented assessment in the sight translation classroom. Current Trends in Translation Teaching and Learning E.

Students reported that the peer evaluator's comments not only helped to improve translation but also broadened the aspects they assumed to be important in judging the translation quality. In particular, they repeatedly raise the benefit of comparison:

When you receive a strict, comprehensive, and detailed oral report of your performance, you would not only think of how to make improvements, but you would also consider the comments and suggestions that he gives to you, and compare with yourself in terms of how to assess the other's performance. [S5]

Peer review is a process of mutual learning. When I listen to her comments, I would always put myself in her position and compare how I would handle the matters and give feedback if I were she. It reminds us to learn from the other's strengths. [S3]

Some mentioned the assignment of designing the evaluation worksheet. The task stimulated their understanding of standards or criteria for translation quality:

I am particularly interested in the activity in which the teacher asks us to create our own criteria for evaluating others. I had to think about what is required to be a good translator, what are the standard rules to follow and so on. [S19] 
Zhang X., Hu W., \& Oergel M. (2021). From skillacquisition to dynamic learning: Learning-oriented assessment in the sight translation classroom. Current Trends in Translation Teaching and Learning E.

My partner and I learned a lot from each other in terms of what to judge and how to judge. For example, I think oral delivery is the most important in sight translation because it is much like a semi-impromptu speech and the audience would look forward to the speaker's tone and manner. But my partner believes accuracy and fluency are as important because it's meaningless to say something that doesn't make sense or isn't true. So, when we were doing the assignment, we merged our criteria together. [S11]

Students also reflected on how they construct assessment criteria and put them into practice. They found that sometimes the broad terms they think of are actually not very useful in practice, and they tried to apply and adapt the criteria in their own practice:

At first, we thought command of language, accuracy and clarity, and oral delivery are the most important criteria. So we put them down on the worksheet. But when we were actually using the criteria, we found they are a bit vague, especially in terms of how we're supposed to define command of language and oral delivery. Then we decided to focus more on details such as grammar and pronunciation issues that would fit our current level... [S17]

\subsubsection{Assessment as a transferable skill}


Zhang X., Hu W., \& Oergel M. (2021). From skillacquisition to dynamic learning: Learning-oriented assessment in the sight translation classroom. Current Trends in Translation Teaching and Learning E.

In addition, a few students recognised that the assessment skill is transferable and therefore can contribute to future development on a variety of occasions:

Evaluating each other is not only useful in sight translation, but we can also use the skill in other aspects of learning and working. In real work settings, employees need to have the ability to give feedback to their team members, leaders, and clients, and to provide feasible solutions as well. [S16]

I guess I got a pair of critical eyes from that. When I think from the reviewer's perspective, it's really different. Next time when I attend an interview or something, I would think about the expectation that the interviewer may hold towards me. [S2]

In this sense, the assessment tasks enabled students to have an alternative and critical perspective on the study and work in general. This finding is in line with the intended outcome of LOA that fostering assessment literacy in students is a key step to developing a sustainable, lifelong disposition of self-evaluation (Boud, 2000; Carless, 2009).

\subsection{Enhancing Reflective and Future Learning}

As mentioned in Section 3, peer feedback and teacher feedback are important elements in providing students with just-in-time feedback on 
Zhang X., Hu W., \& Oergel M. (2021). From skillacquisition to dynamic learning: Learning-oriented assessment in the sight translation classroom. Current Trends in Translation Teaching and Learning E.

their own learning, and on the criteria needed to do better in the future (Pearlman, 2010). This design feature corresponds to the third principle of LOA that "feedback should be timely and forwardlooking so as to support current and future student learning" (Carless, 2009, p. 5). As students reflected, peer feedback has the advantage of providing prompt feedback (see 4.3.1.) which enables them to capture specific errors and pitfalls. This corresponds to the timeliness and comprehensiveness of feedback in LOA. At the same time, teacher feedback is recognised to be effective and tailored to the majority (see 4.3.2.). It ensures that translation performance is appraised with a proper solution for improvements.

\subsubsection{In-time feedback}

According to the students, working with peers allows for immediate feedback on issues that they would otherwise simply let go of or pay little attention to. We infer that this is related to the working mode of sight translation. In sight translation, the output is rendered orally and instantaneously, which leaves little time to capture specific errors, imprecision, or inappropriateness of language, and thus poses more challenges to selfevaluation than in the case of written translation. Peer evaluation makes up for this in that errors can be pinpointed instantly by peers:

Once I finish the delivery, all left in my head is I did it, and the job is finally done. I spare no time to reflect on the quality of the 
Zhang X., Hu W., \& Oergel M. (2021). From skillacquisition to dynamic learning: Learning-oriented assessment in the sight translation classroom. Current Trends in Translation Teaching and Learning E.

delivery and just leave it that way. Then I'll probably forget everything. When translating next time, I start with something new. But things are different with a partner. He always pinpoints everything that I omit or mistranslate or tells me some strategies that he thinks are better. While he is translating, I try my best to do the same for him. This also pushes me to think and reflect. Otherwise, I just keep practising while having no idea if I am making any progress, or I may just make the same mistake all the time without knowing it. [S20]

I guess it is due to short-term memory that no one can perfectly recall what he or she just said. So it is not easy to reflect on what mistakes I have made. But as long as someone's listening to me, they can tell me afterwards even the tiniest issue such as wrong tense or if any information is missing. [S3]

Oral delivery is an aspect of translation quality the students particularly mention as posing various and individual challenges. Students reflect that it is useful when they are constantly reminded of their delivery, or even interrupted if necessary:

My partner's opinion is useful. Every time she would remind me of keeping a louder and clearer voice. I really appreciate that. That's something I wouldn't notice myself. [S12] 
Zhang X., Hu W., \& Oergel M. (2021). From skillacquisition to dynamic learning: Learning-oriented assessment in the sight translation classroom. Current Trends in Translation Teaching and Learning E.

Well, she was like training me. She kept a record of each time I slowed down or got jammed and explained to me what I should improve after I finished translating. These aspects are not book knowledge that I can learn myself. I need such a person to tell me about them. [S18]

In view of the above statements, it can be found that students received feedback from their peers in a rather detailed way and more quickly. It is especially evident that this immediate feedback addresses detailed issues and allows for immediate error correction more efficiently. Instant feedback pinpointing each error meticulously is probably more useful to students than prolonged overall feedback. Also, peer feedback is mentioned as particularly beneficial when practising oral delivery. As noted by Carless (2009), immediate feedback ensures that students can engage with the feedback effectively and act upon it. In this vein, learners' response to feedback is crucial as to whether the feedback can 'feedforward' into future learning. However, it takes time to see whether learners can benefit from engaging with and acting upon feedback. Without understanding whether and to what extent students take actions based on feedback, which is out of the scope of this study, we cannot state with certainty that feedback loops are completely closed.

\subsubsection{Effective classroom management}


Zhang X., Hu W., \& Oergel M. (2021). From skillacquisition to dynamic learning: Learning-oriented assessment in the sight translation classroom. Current Trends in Translation Teaching and Learning E.

Compared to traditional training, many students reflected that when using peer evaluation, classroom management is more efficient. LOA maximizes the use of teaching and learning time and allows the teacher the overall command of the class. Through peer evaluation and feedback, the teacher does not have to give one-to-one feedback, and thus can spend more time and energy in commenting on major pitfalls and on students' translation strategies. The teacher can efficiently direct the attention of the class to the most commonly occurring errors, and provide solutions by sharing essential translation strategies:

It (the peer task) is a very effective way to do this because the teacher could ask us what the most common problems are and give solutions. Commenting on everyone would be very time-consuming. [S1]

When we are doing the peer task, the teacher always moves around the classroom, listening to our discussions and collecting issues that we commonly encounter. Then after peer work, she would lead us to discuss those issues. We would be more willing to engage in the discussion because the problems are what we have faced and we really want to hear others' opinions and think of the best way to solve them. [S15]

Although some scholars have argued that peer evaluation requires increased time on the task, and 
Zhang X., Hu W., \& Oergel M. (2021). From skillacquisition to dynamic learning: Learning-oriented assessment in the sight translation classroom. Current Trends in Translation Teaching and Learning E.

is therefore more time-consuming than traditional assessment, because teachers have to spend extra time evaluating and processing peer feedback results (Liu \& Carless, 2006; Topping, 2009). In this case of sight translation, however, there is no such concern as re-checking peer feedback, as peer evaluation in this classroom is formative in nature. It does not comprise the final grade of student performance as a score or rank, but constitutes a part of the learning process. Teachers are supposed to provide guidance for carrying out assessment tasks instead of evaluating peer feedback outcomes. The implication here is that peer feedback is probably more suited to formative assessment design; it may achieve undesirable results if used for summative purposes. If it is properly combined with teacher feedback, both timeliness and effectiveness can be achieved.

\subsection{Other Additional Comments}

Despite praise, one concern was predominantly raised. Nine out of twenty students mentioned that they were concerned that they were not professional enough to judge others' performance. In most cases, the evaluator can only pinpoint the errors or imprecisions in delivery. They are unable to offer better suggestions for correction or improvement, due to lack of experience or lack of advanced translation knowledge. This concern is closely related to their lack of evaluation training or experience, which may partly be explained by the fact that the course curriculum does not include any introductory modules in assessment criteria. 
Zhang X., Hu W., \& Oergel M. (2021). From skillacquisition to dynamic learning: Learning-oriented assessment in the sight translation classroom. Current Trends in Translation Teaching and Learning E.

The problem is that we can tell each other our errors and mistakes, but we are unable to get a perfect solution. So lots of peer exercises actually can't help to enhance our sight translating skills [...], at least we can't come up with some good strategies without any guidance or help from the teacher.[S5]

There were also other issues regarding peer work. One student found that they had disagreements on translation issues, which made the activity less effective; the other talked about the intricate relationship between the translator and the evaluator.

It's very frustrating when we have disagreements, especially when it comes to how to translate a sentence or a phrase best. We would spend lots of time discussing that and not coming to a satisfying conclusion. [S1]

Our translation skills are not as good as experts. So I worry that my comments may be not helpful or even wrong. I also don't trust much about my partner's suggestions, but I always accept it because I don't want to hurt her feelings or it's too troublesome to raise my own opinion. I even don't know if mine is right. [S18]

As they described, when the group of two disagree, the student playing the translator role would either pretend to accept it but remain privately doubtful, or 
Zhang X., Hu W., \& Oergel M. (2021). From skillacquisition to dynamic learning: Learning-oriented assessment in the sight translation classroom. Current Trends in Translation Teaching and Learning E.

express their opinion directly. Either situation decreases trust between the pair, making the activity less enjoyable. Perhaps clearer instructions from the teacher or a demonstration of exemplary performance could be useful to give direction and strengthen students' confidence in the activity.

\section{CONCLUSION AND IMPLICATIONS}

This study explores the educational model of LOA in a specialised translation classroom. A case of sight translation module design based on the LOA model is presented, in which the three LOA principles are integrated into a sequence of in-class and after-class activities, including peer evaluation and feedback, teacher feedback, teacher-led discussion and joint construction of assessment criteria. The classroom design showcases how learning and assessment can be integrated into translator education. From the students' perspectives, the assessment activities are encouraging and stimulating; they provide opportunities to receive prompt feedback, to simulate interpreting tasks in the real world, to promote collaborative learning with their fellow students, to promote motivation and self-regulation, to better manage the in-class activities, to facilitate students' engagement in learning, and to help them build up assessment skills. Specific learner perceptions are linked with actual assessment tasks implemented in the sight translation, which are then aligned with LOA principles and design features.

The study is an innovative attempt to holistically 
Zhang X., Hu W., \& Oergel M. (2021). From skillacquisition to dynamic learning: Learning-oriented assessment in the sight translation classroom. Current Trends in Translation Teaching and Learning E.

examine the learning process, including learning objectives, pedagogical materials and tasks, assessment, and learner feedback, through an established educational model. It offers implications for theorising translation teaching and assessment. This study showcases how a theoretical framework can be empirically examined, and assessment practice conceptually consolidated, providing a case in which teaching, learning, and assessing are integrated, and learners are placed at the centre of assessment. Moreover, it approaches assessment from an educational perspective. The LOA model is shown to be particularly suited to translation classrooms such as those in the case study. Many LOA elements or constructs are in line with the ethos of translation teaching, such as cooperation and task authenticity. In a broader context, the LOA model can be incorporated into teaching other translation and interpreting modules, where applicable and feasible.

Shortcomings must also be acknowledged. The focus of this study is primarily on the students' perceptions; however, multiple perspectives from more stakeholders, such as teachers, module developers, and assessment experts, could also be included in future research. As this study is limited in its scope, language pairs other than EnglishChinese could be included, and classroom activities other than sight translation should also be investigated. Research into how teachers manage assessment activities, for example, how they provide instructions on constructing assessment criteria, is also clearly needed, as well as whether 
Zhang X., Hu W., \& Oergel M. (2021). From skillacquisition to dynamic learning: Learning-oriented assessment in the sight translation classroom. Current Trends in Translation Teaching and Learning E.

this model can lead to improved learning outcomes. Carless (2009) mentioned the use of a quality exemplar to facilitate students' understanding of standards or the criteria for quality, which the current study did not include. This may associate with students reporting in interviews that they suffered from a lack of confidence in drafting criteria or in commenting on others' performances, owing to their poor impressions of their own linguistic and translation competence. More details can be teased out if future research explores this further. In addition, data on long-term student development as a result of engaging with and acting upon feedback was not collected in the current study. This also offers a starting point for future research.

\section{ACKNOWLEDGEMENTS}

This work is supported by the grant received from the Jiangsu "Innovation and Entrepreneurship" Talent Programme. We want to express our gratitude to all the participants in this study and the editor and reviewers of CTTL $E$ for their valuable comments and insightful suggestions. 
Zhang X., Hu W., \& Oergel M. (2021). From skillacquisition to dynamic learning: Learning-oriented assessment in the sight translation classroom. Current Trends in Translation Teaching and Learning E.

\section{REFERENCES}

Abdel Latif, M. M. M. (2018). Towards a typology of pedagogy-oriented translation and interpreting research. The Interpreter and Translator Trainer, 12(3), 322-345. https://doi.org/10.1080/1750399X.2018.1502008

Al-Qinai, J. (2000). Translation Quality Assessment. Strategies, Parametres and Procedures. Meta : journal des traducteurs / Meta: Translators' Journal, 45(3), 497-519. https://doi.org/10.7202/001878ar

Boud, D. (2000). Sustainable Assessment: Rethinking assessment for the learning society. Studies in Continuing Education, 22(2), 151-167. https://doi.org/10.1080/713695728

Boud, D., \& Falchikov, N. (2007). Rethinking Assessment in Higher Education: Learning for the Longer Term. Routledge.

Butler, D. L., \& Winne, P. H. (1995). Feedback and SelfRegulated Learning: A Theoretical Synthesis. Review of Educational Research, 65(3), 245-281. https://doi.org/10.3102/00346543065003245 
Zhang X., Hu W., \& Oergel M. (2021). From skillacquisition to dynamic learning: Learning-oriented assessment in the sight translation classroom. Current Trends in Translation Teaching and Learning E.

Carless, D. (2007). Learning-oriented assessment:

Conceptual bases and practical implications. Innovations in Education and Teaching International, 44(1), 57-66. https://doi.org/10.1080/14703290601081332

Carless, D. (2009). Learning-oriented assessment:

Principles, practice and a project. In L. H. Meyer, S. Davidson, H. Anderson, R. Fletcher, P. M. Johnston, \& M. Rees (Eds.), Tertiary Assessment \& Higher Education Student Outcomes: Policy, Practice \& Research (pp. 79-90). Ako Aotearoa.

Carless, D. (2015). Exploring learning-oriented assessment processes. Higher Education, 69(6), 963-976. https://doi.org/10.1007/s 10734-0149816-Z

Carless, D. (2017). Scaling up assessment for learning: Progress and prospects. In D. Carless, S. M. Bridges, C. K. Y. Chan, \& R. Glofcheski (Eds.), Scaling up Assessment for Learning in Higher Education (p. 16). Springer.

Galán Mañas, A. (2016). Learning portfolio in translator training: The tool of choice for competence development and assessment. The Interpreter and Translator Trainer, 10(2), 161-182. https://doi.org/10.1080/1750399X.2015.1103108 
Zhang X., Hu W., \& Oergel M. (2021). From skillacquisition to dynamic learning: Learning-oriented assessment in the sight translation classroom. Current Trends in Translation Teaching and Learning E.

Galán-Mañas, A., \& Hurtado Albir, A. (2015).

Competence assessment procedures in translator training. The Interpreter and Translator Trainer, 9(1), 63-82. https://doi.org/10.1080/1750399X.2015.1010358

Han, C., \& Fan, Q. (2020). Using self-assessment as a formative assessment tool in an English-Chinese interpreting course: Student views and perceptions of its utility. Perspectives, 28(1), 109-125. https://doi.org/10.1080/0907676X.2019.1615516

House, J. (1977). A Model for Translation Quality Assessment. Gunter Narr Verlag.

House, J. (1997). Translation Quality Assessment: A Model Revisited. Gunter Narr Verlag.

House, J. (2015). Translation quality assessment: Past and present. Routledge.

Hu, W. (2018a). Education, Translation and Global Market Pressures: Curriculum Design in China and the UK. Palgrave Macmillan. https://doi.org/10.1007/978-981-10-8207-8 
Zhang X., Hu W., \& Oergel M. (2021). From skillacquisition to dynamic learning: Learning-oriented assessment in the sight translation classroom. Current Trends in Translation Teaching and Learning E.

Hu, W. (2018b). Revisiting Translation Quality Assurance: A Comparative Analysis of Evaluation Principles between Student Translators and the Professional Trans-editor. World Journal of Education, 8(6), 176. https://doi.org/10.5430/wje.v8n6p176

Huertas Barros, E., \& Vine, J. (2018). Current trends on MA translation courses in the UK: Changing assessment practices on core translation modules. The Interpreter and Translator Trainer, 12(1), 524.

https://doi.org/10.1080/1750399X.2017.1400365

Huertas Barros, E., \& Vine, J. (2019). Training the trainers in embedding assessment literacy into module design: A case study of a collaborative transcreation project. The Interpreter and Translator Trainer, 13(3), 271-291. https://doi.org/10.1080/1750399X.2019.1658958

Hurtado Albir, A. (2007). Competence-based Curriculum Design for Training Translators. The Interpreter and Translator Trainer, 1(2), 163-195. https://doi.org/10.1080/1750399X.2007.1079875 7

Hurtado Albir, A. (2015). The Acquisition of Translation Competence. Competences, Tasks, and 
Zhang X., Hu W., \& Oergel M. (2021). From skillacquisition to dynamic learning: Learning-oriented assessment in the sight translation classroom. Current Trends in Translation Teaching and Learning E.

Assessment in Translator Training. Meta, 60(2), 256-280. https://doi.org/10.7202/1032857ar

Hurtado Albir, A., \& Pavani, S. (2018). An empirical study on multidimensional summative assessment in translation teaching. The Interpreter and Translator Trainer, 12(1), 25-47. https://doi.org/10.1080/1750399X.2017.1420131

Jones, N., \& Saville, N. (2016). Learning Oriented Assessment | Learning Oriented Assessment. Cambridge University Press.

Kelly, D. (2005). A handbook for translator trainers: A guide to reflective practice. St. Jerome Pub.

Keppell, M., \& Carless, D. (2006). Learning-oriented assessment: A technology-based case study. Assessment in Education: Principles, Policy \& Practice, 13(2), 179-191. https://doi.org/10.1080/09695940600703944

Kiraly, D. C. (2000). A social constructivist approach to translator education: Empowerment from theory to practice. St. Jerome Publishing.

Larose, R. (1998). Méthodologie de l'évaluation des traductions. Meta : journal des traducteurs / 
Zhang X., Hu W., \& Oergel M. (2021). From skillacquisition to dynamic learning: Learning-oriented assessment in the sight translation classroom. Current Trends in Translation Teaching and Learning E.

Meta: Translators' Journal, 43(2), 163-186. https://doi.org/10.7202/003410ar

Lee, Y.-H. (2005). Self-assessment as an Autonomous Learning Tool in an Interpretation Classroom. Meta, 50(4), Article 4. https://doi.org/10.7202/019869ar

Li, X. (2018). Self-assessment as 'assessment as learning' in translator and interpreter education: Validity and washback. The Interpreter and Translator Trainer, 12(1), 48-67. https://doi.org/10.1080/1750399X.2017.1418581

Li, X. (2019). Material development principles in undergraduate translator and interpreter training: Balancing between professional realism and classroom realism. The Interpreter and Translator Trainer, 13(1), 18-43. https://doi.org/10.1080/1750399X.2018.1550039

McGarr, O., \& Clifford, A. M. (2013). 'Just enough to make you take it seriously': Exploring students' attitudes towards peer assessment. Higher Education, 65(6), 677-693. https://doi.org/10.1007/s10734-012-9570-z

Munday, J. (2012). Introducing Translation Studies: Theories and Applications. Routledge. 
Zhang X., Hu W., \& Oergel M. (2021). From skillacquisition to dynamic learning: Learning-oriented assessment in the sight translation classroom. Current Trends in Translation Teaching and Learning E.

Orlando, M. (2011). Evaluation of Translations in the Training of Professional Translators: At the Crossroads between Theoretical, Professional and Pedagogical Practices. The Interpreter and Translator Trainer, 5(2), 293-308. https://doi.org/10.1080/13556509.2011.10798822

PACTE group. (2003). Building a translation competence model. In F. Alves (Ed.), Triangulating translation: Perspectives in process oriented research (pp. 43-68). John Benjamins Publishing Company.

Pearlman, B. (2010). Designing New Learning Environments to Support 21st Century Skills. In J. A. Bellanca \& R. Brandt (Eds.), 21 st Century Skills: Rethinking How Students Learn (pp. 116147). Solution Tree.

Pöchhacker, F. (2003). Introducing Interpreting Studies. Taylor \& Francis.

Reiss, K. (2000). Translation criticism-The potentials and limitations: Categories and criteria for translation quality assessment (E. F. Rhodes, Trans.). St. Jerome Publishing. 
Zhang X., Hu W., \& Oergel M. (2021). From skillacquisition to dynamic learning: Learning-oriented assessment in the sight translation classroom. Current Trends in Translation Teaching and Learning E.

Sadler, D. R. (1989). Formative assessment and the design of instructional systems. Instructional Science, 18(2), 119-144. https://doi.org/10.1007/BF00117714

$\mathrm{Su}, \mathrm{W}$. (2019). Interpreting quality as evaluated by peer students. The Interpreter and Translator Trainer, 13(2), 177-189. https://doi.org/10.1080/1750399X.2018.1564192

Veiga Díaz, M. T., \& García González, M. (2016). Constructively Aligned Assessment: An Integral Approach to Translation Teaching and Learning. Meta, 61(2), 276-298. https://doi.org/10.7202/1037760ar

Vygotsky, L. (1978). Mind in society: The development of higher psychological processes. Harvard University Press.

Williams, M. (2004). Translation Quality Assessment: An Argumentation-centred Approach. University of Ottawa Press. 
Zhang X., Hu W., \& Oergel M. (2021). From skillacquisition to dynamic learning: Learning-oriented assessment in the sight translation classroom. Current Trends in Translation Teaching and Learning E.

\section{Appendix 1 Requirement for peer evaluation worksheet design}

1. Design a peer evaluation worksheet (This worksheet should include criteria that reflect your understanding of translation quality for Sight Translation)

2. Illustrate your evaluation for your peer's in-class performance using the worksheet

(This is a written reflection of the classroom peer activity. The worksheet can be in any form, e.g., journal or grading scheme. You are free to refer to any books, journal articles, or research paper that might be of help.) 
Zhang X., Hu W., \& Oergel M. (2021). From skillacquisition to dynamic learning: Learning-oriented assessment in the sight translation classroom. Current Trends in Translation Teaching and Learning E.

\section{Appendix 2 A sample of student assignment}

Peer evaluation worksheet

Text: Chancellor's speech to students at Peking University

\begin{tabular}{|c|c|c|}
\hline Indicators & Grade & Details \\
\hline $\begin{array}{l}\text { Understanding of } \\
\text { subject }\end{array}$ & 95 & 文章的主题和大意理解准确, 没有差错 \\
\hline $\begin{array}{l}\text { Clarity and accuracy } \\
\text { of the message }\end{array}$ & 85 & $\begin{array}{l}\text { 总体信息表述完整清整, 但仍旧存在漏译和错译问题, 漏译主要体现在小细节上, 如 } \\
\text { 一个时间 (June)，几个个动词短语 (candid with...)，几个形容词 (new..)、副词和 } \\
\text { 一些小的名词 (WeChat, scratch...)，这可能是因为句子过长, 在追求结构完整的同 } \\
\text { 时忽略对小词的翻译, 造成句子意思表述不够精准明确; 错译主要表现在数字和一些 } \\
\text { 名词的翻译上, 尤其是数字, 有三处错误, 因此需要加强这方面的练习, 面对于一柴 } \\
\text { 词语意思不理解造成的错译也会影响整个句子的翻译, 使其句子表述不够通顺合理. } \\
\text { 另外还存在补充一柴多余的或者原文未提到的信息, 前者使句子不矽精简干练, 后者 } \\
\text { 造成理解不当. }\end{array}$ \\
\hline $\begin{array}{l}\text { Command of } \\
\text { language }\end{array}$ & 85 & $\begin{array}{l}\text { 翻译句子大多采用順句驱动的模式, 但存在多次重译和回译现象, 多是为了追求完美 } \\
\text { 和结构完整而对原文省略内容 (如主语) 的补充和修改, 或者是因为句中某个词意思 } \\
\text { 的不理解, 进而给整个句子的翻译带来困难, 但也有纯粹是因习惯问题造成的无意识 } \\
\text { 的停顿和回译. 另外还有一处地方, 可能是因为翻页的缘故, 未能和上文内容保持大 } \\
\text { 体结构上的一致, 而这五个句子其实是并列的关系, 她把第五句过于脱离上文, 造成 } \\
\text { 句子衔接上的失当. }\end{array}$ \\
\hline $\begin{array}{l}\text { Use of appropriate } \\
\text { terminology }\end{array}$ & 95 & $\begin{array}{l}\text { 由于事先做了准备, 加上这部分专有名词和术语不多且简单, 因而翻译较为佮当, 反 } \\
\text { 而是有一个普通名词 (security) 因为想太多, 将其译为债券, 造成整个句子理解失误, } \\
\text { 翻译不顺. 另外虽然中国央行就是中国人民银行, 但根据原文, 我认为还是译为人民 } \\
\text { 银行更加合适. }\end{array}$ \\
\hline $\begin{array}{l}\text { Delivery (tone of } \\
\text { voice; clarity of } \\
\text { diction; liveliness; } \\
\text { pace ) }\end{array}$ & 85 & $\begin{array}{l}\text { 翻译时声音平缓清䀿, 音量适中, 对于自己熟悉的句子翻译起来很有自信和力量, 即 } \\
\text { 使句子很长也能够一口乞鳞完不出差错, 但总体而言翻译速度比较缓慢, 有些句子停 } \\
\text { 顿时间过长, 习惯性的出现“楒....额...”等语气词. }\end{array}$ \\
\hline \multicolumn{3}{|c|}{$\begin{array}{l}\text { Overall comments: } \\
\text { 总体表现良好, 把握文章主旨大意, 适时的补充与意译使句子结构更加完整, 表述更加得当. 但翻译时需注意词 } \\
\text { 汇翻译的准确性、完整性以及句子表达是否通肠、符合口语, 尽量避免多处重复和回译, 減少停顿之处和停顿时间, } \\
\text { 适当加快翻译速度. }\end{array}$} \\
\hline
\end{tabular}

